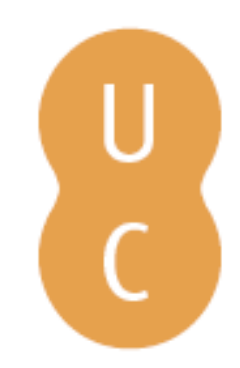

\title{
pommalina
}

\section{Impacts of climate change on the fire regime in Portugal}

Autor(es): $\quad$ DaCamara, Carlos C.; Pereira, Mário G.; Calado, Teresa J.; Calheiros,

Publicado por: Imprensa da Universidade de Coimbra

URL

persistente: URI:http://hdl.handle.net/10316.2/34336

DOI: $\quad$ DOI:http://dx.doi.org/10.14195/978-989-26-0884-6_130

Accessed : $\quad$ 26-Apr-2023 05:43:17

A navegação consulta e descarregamento dos títulos inseridos nas Bibliotecas Digitais UC Digitalis, UC Pombalina e UC Impactum, pressupõem a aceitação plena e sem reservas dos Termos e Condições de Uso destas Bibliotecas Digitais, disponíveis em https://digitalis.uc.pt/pt-pt/termos.

Conforme exposto nos referidos Termos e Condições de Uso, o descarregamento de títulos de acesso restrito requer uma licença válida de autorização devendo o utilizador aceder ao(s) documento(s) a partir de um endereço de IP da instituição detentora da supramencionada licença.

Ao utilizador é apenas permitido o descarregamento para uso pessoal, pelo que o emprego do(s) título(s) descarregado(s) para outro fim, designadamente comercial, carece de autorização do respetivo autor ou editor da obra.

Na medida em que todas as obras da UC Digitalis se encontram protegidas pelo Código do Direito de Autor e Direitos Conexos e demais legislação aplicável, toda a cópia, parcial ou total, deste documento, nos casos em que é legalmente admitida, deverá conter ou fazer-se acompanhar por este aviso.

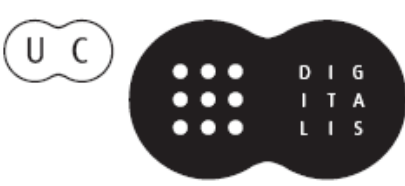




\section{ADVANCES IN}

Forest Fire

\section{RESEARCH}

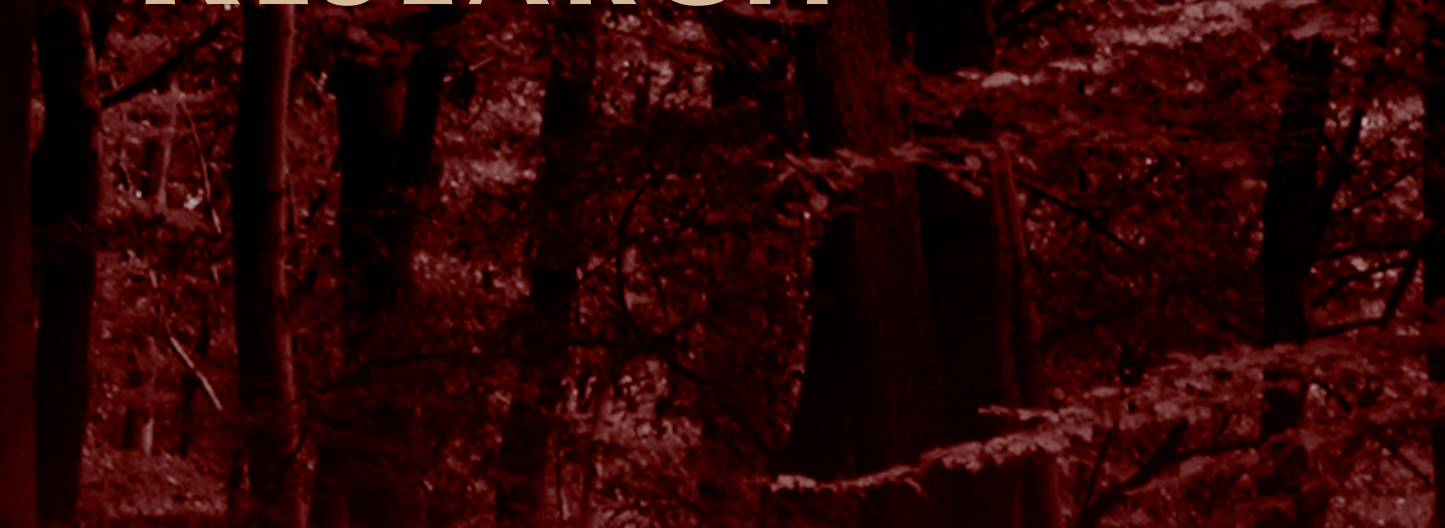

\section{DOMINGOS XAVIER VIEGAS}

\section{EDITOR}




\title{
Impacts of climate change on the fire regime in Portugal
}

\author{
Carlos C. DaCamara ${ }^{a}$, Mário G. Pereira ${ }^{\mathrm{b}, \mathrm{a}}$, Teresa J. Calado ${ }^{\mathrm{a}}$, Tomás Calheiros ${ }^{\mathrm{a}}$ \\ aInstituto Dom Luiz, ,Universidade de Lisboa,Lisboa,Portugal, cdcamara@fc.ul.pt, \\ mtcalado@fc.ul.pt,tlmenezes@fc.ul.pt \\ ${ }^{b}$ Centro de Investigação e de Tecnologias Agro-Ambientais e Biológicas CITAB, Universidade de \\ Trás-os-Montes e alto Douro, UTAD, Quinta de Prados, 5000-801 Vila Real, Portugal, \\ gpereira@utad.pt
}

\begin{abstract}
Wildfires in Portugal are a major problem, with about 18500 fires and 110000 ha burnt every year and an increasing trend of the large fires (>100 ha) during the $1980-2011$ period. In previous studies, climate and weather conditions were identified as the most important drivers of annual total burnt area in the country which inspire assessing potential changes in the statistical distribution of the areas burnt by fires in the expected warmer and drier conditions of future climate. The aim of the study is therefore to project area burnt by vegetation fires in Portugal for different future climate scenarios using an appropriate Burnt Area Model (BAM). The BAM is a multiple regression model that shown to be able to simulate the burnt areas in July and August with just two predictors: the Daily Severe Rating (DSR) in the pre-fire season (May and June) and during the fire season (July and August). Then, the regression model is fed with simulated data by a Global Climate Model (GCM) respecting to present climate and to future IPCC emission scenarios B1 and A1B. It is shown that samples of observed and simulated logarithms of burnt areas follow normal distributions. Changes in measures of location and dispersion (mean and variance), from recent past to future climates, are analysed after statistically removing the effects due to the limitations of the GCM and the BAM. When comparing present climate with future climate scenario B1 (A1B), maximum increases in the averages of the decimal logarithm of July and August burnt area are of $11 \%(28 \%)$ while the standard deviation remaining almost unchanged for scenario B1 and presenting an increase of $25 \%$ for A1B. Obtained estimates need to be looked at with due care but the developed approach consistently points towards an increasing risk of fire under future climate conditions, inter-annual variability and likelihood of having much larger fire events.
\end{abstract}

Keywords: Forest fire; Climate change; GCM; Fire risk/danger

\section{Introduction}

Assessing the potential impacts of climate change on the fire regime is especially relevant in Portugal, where according to the Portuguese National Forest Authority (Instituto de Conservação da Natureza $e$ das Florestas, ICNF) and the European Forest Fire Information System (EFFIS), more 610000 fires and 3,5 million ha have burnt between 1980 and 2012, almost 1 million ha of which between 2003 and 2005 (Calado and Dacamara 2008). Besides, the number of large fires (with more than 100 ha), amount of burnt area (hereafter, BA) and fire severity have lately increased in Portugal (Pereira et al. 2011). Weather and climate are considered the most important drivers of fire activity, even more important than fuel pattern and topography in determining BA in simulated landscapes due to the direct and indirect profound influence they have on wild land fire ignition potential, fire behaviour and severity (Cary and Banks 2000; Benson et al. 2008). The climatic conditions determine the existence, type and life cycle of the vegetation which helps explaining the strong resemblance between the spatial patterns of the global pyrogeography (Krawchuk et al. 2009) and the updated world map of the Köppen-Geiger climate classification (Peel et al. 2007). On the other hand, weather conditions such as lightning promotes fire ignition, while air temperature, wind, atmospheric stability and air relative humidity determine the fuel moisture content and fire spread and, on the contrary, precipitation, even in small amounts, contributes to fire extinction (Pereira et al. 2013). 
Climate and weather play a particularly important role in the fire regime in Portugal, where long-term climatic pre-conditions (e.g. temperature and precipitation in winter and spring before the summer fire peak season) and short-term synoptic forcing (e.g. extreme synoptic weather patterns and weather types from classifications schemes) are able to explain about two thirds of the variance in the annual, seasonal and monthly total BA (Pereira et al. 2005; Pereira et al. 2013; Trigo et al. 2013). Extreme fire activity as recorded in 2003 and 2005 tends to occur under (also) extreme and consistent weather conditions from the surface to high levels of the atmosphere (Trigo et al. 2006) and is related to the evolution of the synoptic- and meso-scale wind, temperature and humidity patterns associated to the appearance of the Iberian thermal low (Hoinka et al. 2009).

These factors are continuously changing due to natural climate variability and human-caused climate change (Stocker et al. 2013) which may contribute to the high inter-annual variability and increasing trends observed in the last decades (Pereira et al. 2005; Pereira et al. 2011) and legitimizes the ambition to try to estimate future fire activity.

Many of the most recent studies on the impacts of climate change on some aspect of the fire regime and wildfires has focus on North (Johnstone et al. 2010; Wotton et al. 2010; Westerling et al. 2011; Rocca et al. 2014) and South America (Silvestrini et al. 2011), Australia (Pitman et al. 2007; Murphy and Timbal 2008; Clarke et al. 2011) Lynch et al., 2007), in boreal forests of North America and Eurasia (Kilpeläinen et al. 2010; Liu et al. 2012; De Groot et al. 2013), in Europe (Moriondo et al. 2006; Batllori et al. 2013; Cane et al. 2013; Bedia et al. 2014; Karali et al. 2014) and even at global scale (Moritz et al. 2012). However, and despite the magnitude of the problem in Portugal, a very short list of studies have dealt with the impact of climate change on wildfire risk in Portugal (Durão and Corte-Real 2006; Carvalho et al. 2008; Carvalho et al. 2010; Pereira et al. 2013).

The projection of future fire activity requires the development of robust and resistant fire-vegetationweather/climate relationships to be used in future climate conditions and the availability of sufficiently long and reliable datasets of observed and simulated values of meteorological and fire variables (Pereira et al. 2013). Portugal holds one of the largest (in terms of total number of recorded fires) and most comprehensive rural fire databases, not only in European context but also in comparison to many other countries worldwide (Pereira et al. 2011).

Currently, a large set of long and reliable meteorological datasets of analysis and reanalysis are available for climate research studies which includes the European Centre for Medium-Range Weather Forecasts (ECMWF) ECMWF 40-year Reanalysis (ERA-40), the ECMWF Interim Reanalysis (ERAInterim), the Japanese 25-year (JRA-25) and 55-year Reanalysis (JRA-55), the NASA Modern Era Reanalysis for Research and Applications (MERRA) and (MERRA2), the National Centers for Environmental Prediction (NCEP) Climate Forecast System Reanalysis (CFSR) and NCEP/DOE Reanalysis II and the NOAA-CIRES 20th Century Reanalysis V2.

On the other hand, General Circulation Models (GCMs) are nowadays recognized as suitable tools for climate modelling because they are based on well-established physical principles, able to simulate global- and many regional-scale observed features of contemporary climate, past climate changes and there is significant confidence that GCM provide credible quantitative estimates of future climate change (Randall and Fichefet 2007). In this sense, most climate models are able to derive fire danger and thereby characterize a probable fire regime (Lynch et al. 2007). In addition, climate change data, which may include climate estimates from observations, socio-economic data and scenarios, global climate model data simulated by different GCM and for different future climate scenarios may be easily obtained from many different data providers such as the Data Distribution Centre (DDC) of the Intergovernmental Panel on Climate Change (IPCC) or the Program for Climate Model Diagnosis and Intercomparison which provides the World Climate Research Programme Coupled Model Intercomparison Project, WCRP CMIP datasets (Meehl et al. 2007). Recently, a Burnt Area Model (BAM) was developed for Portugal based on multiple regression analysis of meteorological parameters with the aim to model the BA during the summer months and be used as a BA generator (Pereira et al. 
2013). Therefore, the aim of this study is to produce and compare projections of future BA in Portugal by means of the BAM for different future climate change scenarios.

\section{Materials and Methods}

This study is based on a fire database and on daily meteorological data of both analysed and simulated fields. Indices of fire risk that integrate the Canadian Forest Fire Danger Rating System (CFFDRS) are then computed using the appropriate meteorological data.

\subsection{Data}

The fire database was provided by the Institute for the Conservation of Nature and Forestry (Instituto da Conservação da Natureza e das Florestas, ICNF) and consist of detailed information (e.g., fire ignition location, in terms of administrative division of Portugal, fire ignition and extinction date and time, fire area in forest, shrublands and agricultural land cover type) obtained from ground measurements for each fire occurred in Continental Portugal between 1980 and 2011. This dataset is an extension of the Portuguese Rural Fire Database (Pereira et al. 2011) and after correcting the additional data for inconsistencies and errors using the same procedures, monthly cumulated values were computed for the considered 32 - year period.

The observed meteorological database consist of analysed fields from the ERA-Interim which is the latest global atmospheric reanalysis produced by the ECMWF to replace the ERA-40 with a new atmospheric reanalysis which will extend back to the early part of the twentieth century and able to provide a better representation the hydrological cycle, improve the quality of the stratospheric circulation and the consistency in time of the reanalysed fields (Dee et al. 2011). The ERA-Interim data server surface archive has a mixture of analysis fields, forecast fields and fields available from both the analysis and forecast which is determined by the step variable: 0 for analysis (which are available for $0000,0600,1200$ and 1800 UTC); 3, 6, 9 or 12 for forecast fields which are produced from forecasts beginning at 0000 and 1200 UTC). The other daily archives have only analysis data.

The selected meteorological fields are: 2 meter air temperature, 2 meter dew point temperature, 10 meter zonal and meridional components of wind speed and 24 hour cumulated precipitation (all at 12 UTC). The air relative humidity was computed with the Magnus formula (using 2 meter air temperature, 2 meter dew point temperature) and corrected according to the altitude. All meteorological fields are defined on a $0.75^{\circ} \times 0.75^{\circ}$ latitude/longitude grid over Continental Portugal. Spatial means were then computed over the selected grid points and monthly means were finally derived for all meteorological data.

The simulated meteorological database consist of outputs from the Model for Interdisciplinary Research on Climate (MIROC), which is a coupled Atmosphere-Ocean GCM that comprises five components, namely atmosphere, land, river, sea ice and ocean. Developers of MIROC are at the Centre for Climate System Research (CCSR), the University of Tokyo, the National Institute for Environmental Studies (NIES) and the Frontier Research Centre for Global Change (FRCGC). Several different model comparison studies identify MIROC as one of the best models (Lucarini et al. 2007; Scherrer 2011; Watanabe et al. 2011; Watanabe et al. 2011; Mochizuki et al. 2012; Chikamoto et al. 2013) with especial good performance over the Iberian Peninsula (Nieto and Rodríguez-Puebla 2006; Errasti et al. 2011).

For comparison purposes, data for three grid points were selected from MIROC 3.2 medres grid, all approximately at the same longitude but at different latitudes: two of them located over Portugal (one in the south and another in the centre) and one at north of Portugal, in Spanish region of Galicia. Daily grid values of $10 \mathrm{~m}$ wind speed, $24 \mathrm{~h}$ cumulated precipitation, surface air temperature and relative humidity were extracted for $1951-2000$ period respecting to the recent past conditions $\left(20^{\text {th }}\right.$ century) model simulations (20C3M), and for the $2051-2100$ respecting to IPCC Special Report on Emissions Scenarios (SRES) B1 and A1B (Nakicenovic and Swart 2000). The B1 scenario corresponds to a high 
level of environmental and social consciousness accompanied by rapid changes in economic structures and the introduction of cleaning technologies. On the other hand, the A1B scenario reflects a future world of very fast economic growth, low population growth, with a rapid introduction of new and more efficient technology, and a balanced mix of technologies and supply sources.

\subsection{The Canadian Forest Fire Weather System}

In this study, the indices of the Canadian Forest Fire Weather Index (FWI) were used to account for the effect of weather on fuels and fire behaviour. The FWI System (Figure 1) comprises six components: the first three components, the Fine Fuel Moisture Code (FFMC), the Duff Moisture Code (DMC) and the Drought Code (DC), are fuel moisture codes which aim respectively to rate the moisture content of litter and other fine fuels, the average moisture content of loosely compacted organic layers of moderate depth, and the average moisture content of deep, compact organic layers; the remaining three components, the Initial Spread Index (ISI), the Build Up Index (BUI) and the Fire Weather Index (FWI), are fire behavior indices, which characterize the rate of fire spread, the fuel available for combustion, and the frontal fire intensity (Van Wagner and Pickett 1985; Van Wagner 1987). Finally, the Daily Severity Rating (DSR) is simply a power function of FWI $\left(\mathrm{DSR}=0.0272 \times \mathrm{FWI}^{1.77}\right)$, with the aim to rate the difficulty of controlling fires and specifically designed for averaging either in time or in space in opposition to FWI that is suitable as a single day value. All these indices are computed solely with the values of four meteorological variables and their values increase with the rise of fire danger (Van Wagner and Pickett 1985). The FWI System was developed for Canada but has been successfully used all over the world (Amiro et al. 2005; Wotton 2009) and shown to be especially useful in Portugal to assess the fire behaviour potential in maritime pine stands (Palheiro et al. 2006) and to rate fire risk in Portugal during the summer season (Rainha et al. 2002; Viegas et al. 2004; Carvalho et al. 2008; Carvalho et al. 2010). Since 1998, the System has been operationally used by the Portuguese Weather Service.

Values of the FWI and DSR derived on selected grid points based on daily values of the above-listed meteorological values (analysed and simulated) and then, spatial averages were computed over grid points and monthly means were finally computed.

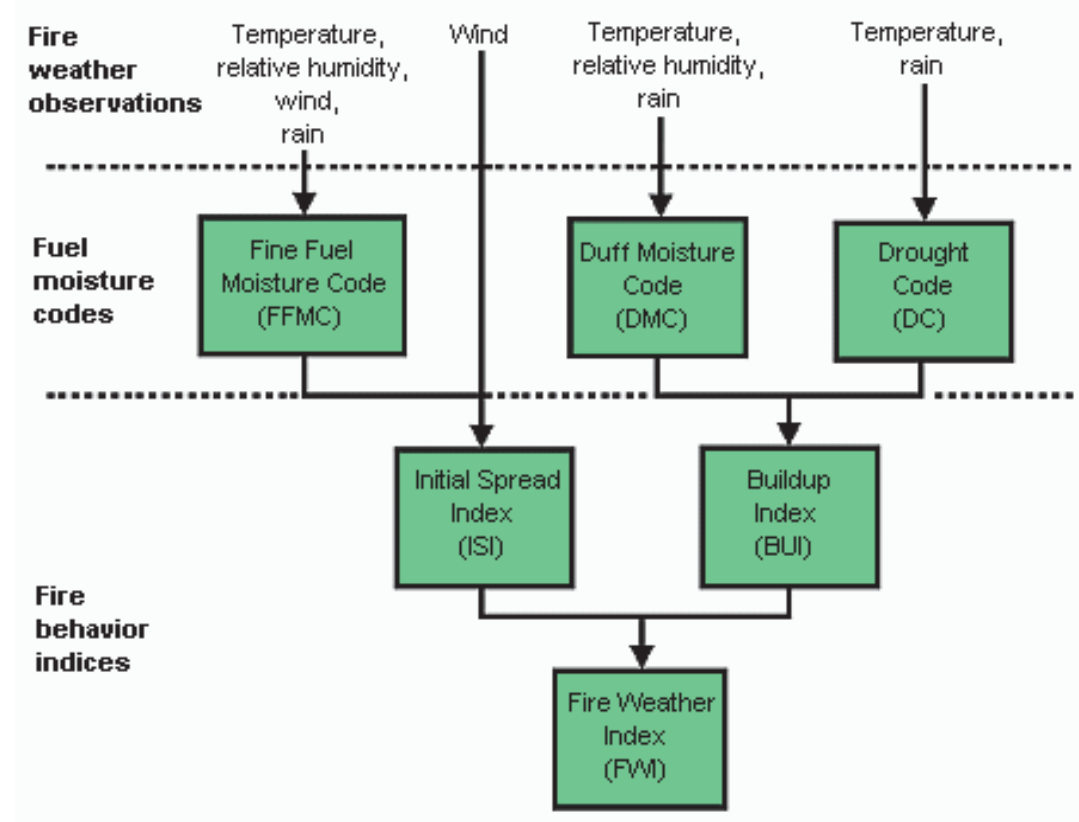

Figure 1. The Structure of the FWI System. The components of the FWI System are computed with consecutive daily observations of air temperature, relative humidity, wind speed, and 24-hour rainfall. The six standard components provide numeric ratings of relative potential for wildland fire. Adapted from Natural Resources Canada (http://cwfis.cfs.nrcan.gc.ca/background/summary/fwi). 


\section{Results}

\subsection{The observed summer burnt areas}

The annual cycle of monthly BA for Continental Portugal during the considered $32-$ year period is shown in Table 1. It is well apparent that the vast majority of area burnt by forest $(71 \%$ of the total BA) take place during the summer months of July and August. The close agreement between the time series of annual and July plus August BA and the very large inter-annual variability dominated by the outstanding values registered in the years of 2003 and 2005 (Figure 2) suggest that the annual fire regime is dominated by the events that take place in July and August and to restrict the study to those two summer months.

Table 1. Annual cycle of monthly burnt area in Portugal for the period $1980-2011$. Values of simple and robust and resistant statistics including the maximum, upper quartile (Q3) median, lower quartil (Q1), minimum, interquartile range (IQR), range and total.

\section{Burnt area (ha)}

\begin{tabular}{|c|c|c|c|c|c|c|c|c|c|c|c|c|}
\hline Statistics & Jan & Feb & Mar & Apr & May J & Jun & Jul & Aug & Sep & Oct & Nov I & Dec \\
\hline Maximum & 1100 & 3118 & 14780 & \11360\} $&{3987} &{18962} &{\checkmark 99087} &{261481} &{66015} &{27606} &{\text { |9157| }} &{3734} \\
{\hline \text { Q3 }} &{115} &{513} &{2161} &{1447} &{1074} &{6197} &{43856} &{60237} &{25123^{1}} &{4548^{\prime}} &{102^{\prime \prime}} &{93} \\
{\hline \text { Median }} &{34^{\prime}} &{124^{\prime}} &{585} &{352\rceil} &{372} &{2112} &{16780} &{30779} &{11679 \rrbracket} &{1632^{\prime}} &{18^{\circ}} &{17} \\
{\hline \text { Q1 }} &{10^{\prime}} &{12^{\prime}} &{85^{\prime}} &{109^{\prime \prime}} &{145} &{555} &{7979} &{18337} &{6246} &{479^{\circ}} &{2^{\prime \prime}} &{\text { 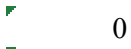 }} \\
{\hline \text { Minimum }} &{0} &{0} &{3} &{0} &{3^{7}} &{27} &{529} &{3571} &{3325^{\circ}} &{0 "} &{0^{F}} &{\text { 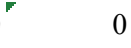 }} \\
{\hline \text { IQR }} &{106} &{501} &{2076} &{1338} &{929} &{5643} &{35877} &{41900} &{\text { 18877 }} &{4069} &{100} &{93} \\
{\hline \text { Range }} &{1100} &{3118} &{14777} &{11360} &{3983 \text { ] }} &{18935} &{98559} &{257910} &{62690} &{27606} &{9157} &{3734} \\
{\hline \text { Total }} &{4775} &{14247} &{67787} &{36393\rceil} &{21801]} &{140834} &{845584} &{1612525} &{574751} &{122332^{\prime \prime}} &{13206^{\prime}} &{5908} \\
{\hline \text { Total (\%) }} &{0 \%} &{0 \%} &{2 \%} &{1 \%} &{1 \%} &{4 \%} &{24 \%} &{47 \%} &{17 \%} &{4 \%} &{0 \%} &{0 \%} \\
$\hline
\end{tabular}

This behaviour is expected in Mediterranean regions since vegetation presents elevated levels of water stress as induced by periods of dry conditions and relatively high temperatures that often characterise the late spring and the beginning of summer (Viegas et al. 2001; Pereira et al. 2005; Trigo et al. 2006). The inter-annual variability (as measured by the inter-quartile range) is also clearly larger during the summer months and it is worth noting that the variability of July and August is about twice the one of September.

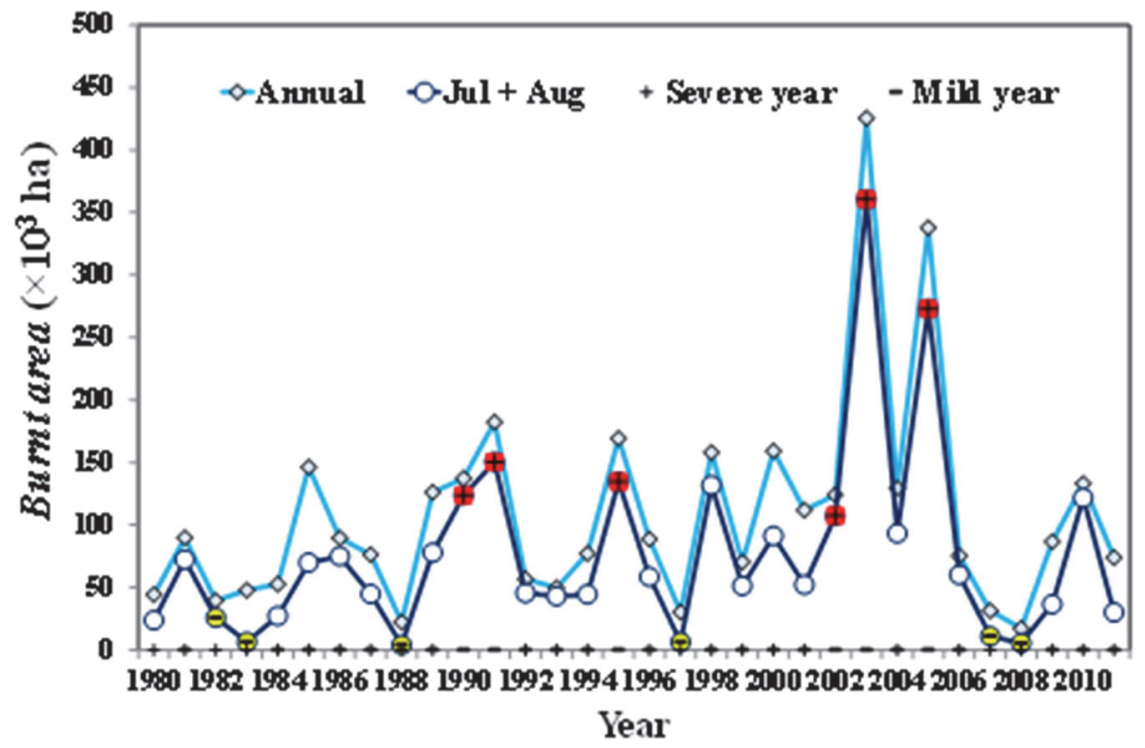

Figure 2. Inter-annual variability of burnt area amounts in Continental Portugal for the whole year (Annual) and just for July + August (Jul + Aug), for the period 1980-2011. Severe (+) and mild (-) years signs inside respective red and yellow circles. 
It is also important to underline some of the results of correlation analysis during the period 1980 - 2011, namely: $(i)$ the existence of a positive and statistical significant (p-value $<0.0001)$ value of the Pearson Product-Moment correlation coefficient $(r=0.66)$ between the areas burned in July and in August; (ii) the very low $(r=0.22)$ and statistically not significant correlation between the DSR monthly means of July and August; (iii) despite the significant ( $\mathrm{p}$-value $<0.0001$ ) high value of the correlation coefficient between DSR and the decimal logarithm of monthly BA for the months of July and August, $(r=0.76$ and $r=0.59$, respectively). These results underline the usefulness of the DSR to rate the meteorological fire danger and suggests the existence of a pre-summer season climatological background that would condition the fire regimes of both July and August.

\subsection{The Burnt Area Model}

With the aim of identifying the most promising predictors of BA in July and August and characterizing the climatological background, a composite analysis (Pereira et al. 2005; Trigo et al. 2006) of all the analysed meteorological fields was performed for two classes of extreme summer fire seasons, respectively severe and mild (Figure 2), defined depending on the monthly BA of July and August are both greater/lesser than the upper/lower tercile of the respective month (i.e. greater than 40,000 ha for July and 46,000 ha for August).

Results reveal that, from the meteorological standpoint, major differences between mild and severe years may be found during the months preceding and during the summer fire season (Figure 3 ). In the pre fire season, severe years are associated to positive anomalies of precipitation in the early spring (March), which favours the growth of vegetation, followed by significant negative anomalies of precipitation and air relative humidity and positive air temperature anomalies in May and June. This climatic pattern is consistent with the atmospheric circulation from NE, over Portugal during this period and, as expected, the increasing trend of positive DSR anomalies from April to June reflect the above-described cumulative behaviour of temperature, relative humidity, wind and precipitation. During the fire season, major statistically significant differences between severe and mild fire seasons are naturally found in all meteorological variables and, consequently, in DSR. Severe fire seasons are characterised by extreme negative precipitation and humidity anomalies and positive temperature anomalies associated to south-eastern winds leading to utmost DSR anomalies. In the case of mild years, the opposite behaviour is observed. 

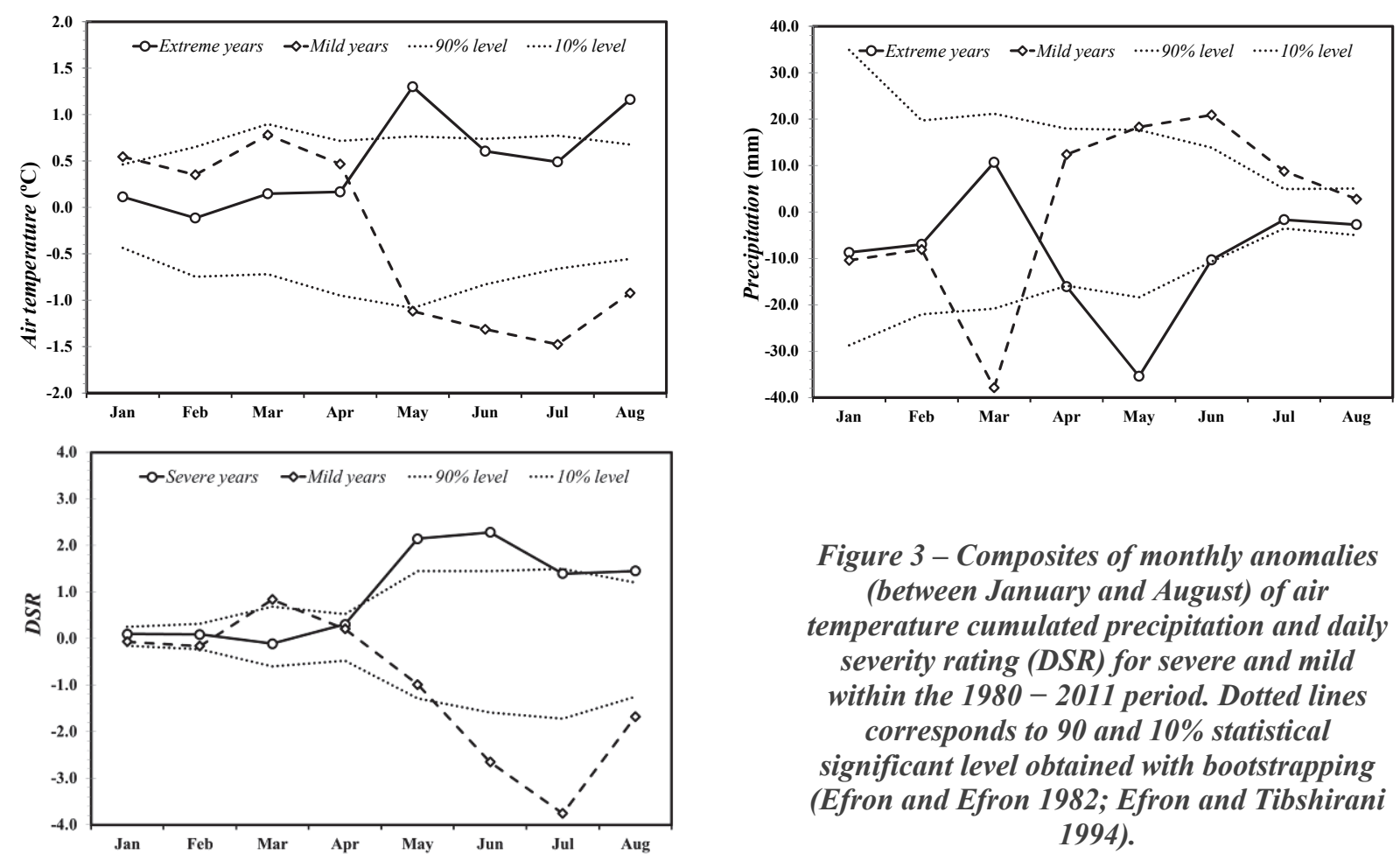

Figure 3 - Composites of monthly anomalies (between January and August) of air temperature cumulated precipitation and daily severity rating (DSR) for severe and mild within the 1980 - 2011 period. Dotted lines corresponds to 90 and 10\% statistical significant level obtained with bootstrapping (Efron and Efron 1982; Efron and Tibshirani 1994).

These results suggest the development of a multiple linear regression BAM for decimal logarithm of monthly BA (due to the highly asymmetrical character of monthly BA) in summer months using, as predictors, meteorological variables and/or fire risk indices respecting to the pre-fire and/or fire seasons. In order to mitigate the effects of over fitting, the performance of the experiments was evaluated using a leave-one-out-cross validation scheme (Wilks 2011). Several selection methods (e.g., stepwise, forward, backward and explained variance) using different criteria were tested to select the best and parsimonious BAM for BA time series in July, August and July + August for the 32-year period using the equation presented in Table 2 where the $\log _{10} \mathrm{BAJ} / \mathrm{A}$ is the decimal logarithm of monthly BA in July or in August; DSR ${ }_{P F}$ is the monthly mean of DSR during the pre-fire period (PF), defined as May and June when the predictand is the decimal logarithm of monthly BA in July $\left(\log _{10} \mathrm{BAJ}_{\mathrm{J}}\right)$ and May, June and July when the predictant is the decimal logarithm of monthly BA in August $\left(\log _{10} \mathrm{BAA}_{\mathrm{A}}\right)$; $\log _{10} \mathrm{BAJ} / \mathrm{A}$ is the monthly mean of DSR in July or in August depending if the predictand is the monthly BA in July or August, respectively. 
Table 2 - Burnt Area Model regression and ANOVA analysis for July, August, and July + August (1980 - 2011). Statistics includes which includes: regression coefficients $(A, B$ and $C)$ and St. Error, $R^{2}$, adjusted $R^{2}\left(R^{2}{ }_{a d j}\right) F$-statistic (Regression $F$ ) and significance of $F$ (Significance $F$ )

Regression and ANOVA analysis

\begin{tabular}{|c|c|c|c|c|c|c|c|}
\hline \multicolumn{8}{|c|}{$\log _{10} B A_{J / A}=A+B \times D_{S R} / A+C \times \mathbf{D S R}_{\mathbf{P F}}$} \\
\hline \multirow{9}{*}{$\stackrel{\grave{\Xi}}{\Xi}$} & \multicolumn{4}{|c|}{ Regression stats Coefficients } & \multirow{2}{*}{$\begin{array}{r}\text { St. error } \\
0.2650\end{array}$} & \multirow{2}{*}{$\begin{array}{r}\boldsymbol{t} \text { S Stat } \\
9.4163\end{array}$} & \multirow{2}{*}{$\frac{P \text {-value }}{0.0000}$} \\
\hline & $\boldsymbol{R}$ & 0.78 & $\mathbf{A}$ & 2.4952 & & & \\
\hline & $\mathbf{R}_{\text {adj }}$ & 0.75 & B & 0.0973 & 0.0336 & 2.8921 & 0.0072 \\
\hline & St. Error & 0.36 & C & 0.1009 & 0.0233 & 4.3326 & 0.0002 \\
\hline & \multicolumn{7}{|c|}{ ANOVA } \\
\hline & \multirow{3}{*}{\multicolumn{2}{|c|}{$\begin{array}{c}\text { Regression } \\
\text { Residual }\end{array}$}} & $d f$ & $S S$ & $M S$ & \multicolumn{2}{|c|}{ Regression $F$ Significance $F$} \\
\hline & & & 2 & 5.7904 & 2.8952 & 21.9352 & $1.58 \mathrm{E}-06$ \\
\hline & & & 29 & 3.8277 & 0.1320 & & \\
\hline & To & & 31 & 9.6181 & & & \\
\hline \multirow{9}{*}{ 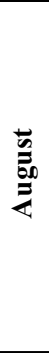 } & \multicolumn{4}{|c|}{ Regression stats Coefficients } & St. error & t Stat & P-value \\
\hline & $R$ & 0.77 & $\mathbf{A}$ & 2.4715 & 0.3104 & 7.9632 & 0.0000 \\
\hline & $\mathbf{R}_{\text {adj }}$ & 0.75 & B & 0.1005 & 0.0295 & 3.4003 & 0.0020 \\
\hline & St. Error & 0.32 & $\mathbf{C}$ & 0.1072 & 0.0247 & 4.3353 & 0.0002 \\
\hline & \multicolumn{7}{|c|}{ ANOVA } \\
\hline & \multirow{4}{*}{\multicolumn{2}{|c|}{$\begin{array}{c}\text { Regression } \\
\text { Residual } \\
\text { Total }\end{array}$}} & $d f$ & $S S$ & $M S$ & \multicolumn{2}{|c|}{ Regression $F$ Significance $F$} \\
\hline & & & 2 & 4.4198 & 2.2099 & 21.7332 & $1.71 \mathrm{E}-06$ \\
\hline & & & 29 & 2.9488 & 0.1017 & & \\
\hline & & & 31 & 7.3686 & & & \\
\hline \multirow{9}{*}{ 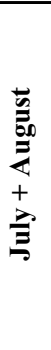 } & \multicolumn{4}{|c|}{ Regression stats Coefficients } & St. error & t Stat & P-value \\
\hline & $R$ & 0.80 & $\mathbf{A}$ & 2.4952 & 0.2650 & 9.4163 & 0.0000 \\
\hline & $\mathbf{R}_{\text {adj }}$ & 0.79 & B & 0.0973 & 0.0336 & 2.8921 & 0.0072 \\
\hline & St. Error & 0.34 & $\mathbf{C}$ & 0.1009 & 0.0233 & 4.3326 & 0.0002 \\
\hline & \multicolumn{7}{|c|}{ ANOVA } \\
\hline & \multirow{4}{*}{\multicolumn{2}{|c|}{$\begin{array}{c}\text { Regression } \\
\text { Residual } \\
\text { Total }\end{array}$}} & $d f$ & $S S$ & $M S$ & \multicolumn{2}{|c|}{ Regression $F$ Significance $F$} \\
\hline & & & 2 & 11.7115 & 5.8557 & 52.2081 & $6.11 \mathrm{E}-14$ \\
\hline & & & 61 & 6.8419 & 0.1122 & & \\
\hline & & & 63 & 18.5533 & & & \\
\hline
\end{tabular}

Results of the regression analysis and analysis of variance (ANOVA) obtained independently for July and August (Table 2) are very similar for both months not only in what respects to regressions statistics $\left(R^{2}=0.59\right.$ $0.61, R^{2}$ adj $=0.56$ and standard error of 0.32 (August) - 0.36 (July), respectively), regression coefficients (A, B and C), statistical significance (Student's $t$ distribution statistic and significance of $F$-statistic). Results for BA in July and August (jointly) are even slightly better $\left(R^{2}=0.64\right.$, $\left.R^{2}{ }_{\text {adj }}=0.62\right)$ but regression coefficients are very similar to those obtained independently for July and August.

The two predictors are statistically significant and were selected in the same order they appear in the equation, with increasing $R^{2}$ value from 0.44 , when $\log _{10} \mathrm{BAJ} / \mathrm{A}$ is the only predictor, to 0.630 when the model has both predictors. Several other aspects are worth being noted namely: the overall good agreement between observed and modelled values of the decimal logarithm of BA; the relatively high value of the coefficient of determination $R^{2}=0.64 \quad(\mathrm{p}$ value $<0.001$ ) for July and August BA; which means that the BAM is able to

explain, in cross-validation mode, almost $3 / 5$ of the total variance. Finally, the normality of the values of the logarithm of the values of BA observed, modelled and residuals from the use of the BAM was confirmed by the Kolmogorov-Smirnov test. All these features are especially important and will be exploited in the next subsection when the BAM will be used as a generator of monthly BA scenarios in recent past and future climate conditions.

\subsection{The simulated summer burnt areas}

Simulated time series of BA in July and August were generated by feeding the BAM with DSR values computed for the pre-fire period and for the fire season with GCM outputs respecting to present $(20 \mathrm{C} 3 \mathrm{M})$ and to future B1 and A1B climate scenarios. The Kolmogorov-Smirnov (K-S) test was used to check that the simulated BA for all cases are normally distributed at the $5 \%$ significant level (Table $3)$. Values of the mean and standard deviations of $\log _{10} \mathrm{BAJ} / \mathrm{A}$ reveal that, as expected, the use of the multiple linear models with observed DSR leads to a simulated BA samples with the same mean as the one of the observed sample but with smaller variance. However, when feeding the BAM with 
Table 3 - Mean, standard deviation (SD) and p-value of the one-sample Kolmogorov-

Smirnov test for normality of burnt area time series for July and August observed and simulated by the BAM when fed with ERAInterim (Modelled) and with GCM outputs $(B A M+M I R O C)$ for different periods of scenario B1 and $A 1 B$.

\begin{tabular}{|c|c|c|c|c|c|}
\hline Model & Scenario & Period & Mean & SD & p \\
\hline & Observed & $1980-2011$ & 4.31 & 0.54 & 0.41 \\
\hline & Modelled & $1980-$ & 4.31 & 0.43 & 0.85 \\
\hline \multirow{5}{*}{$\begin{array}{c}\text { BAM } \\
+ \\
\text { MIROC }\end{array}$} & & $1971-2000$ & 5.06 & 1.06 & 0.42 \\
\hline & & $2051-$ & 5.63 & 0.72 & 0.38 \\
\hline & & $2071-2100$ & 6.03 & 1.07 & 0.68 \\
\hline & \multirow[b]{2}{*}{ A1B } & $2051-2080$ & 6.72 & 0.97 & 0.68 \\
\hline & & $2071-2100$ & 7.48 & 1.36 & 0.29 \\
\hline
\end{tabular}

simulated data by a GCM for future climate scenarios there is an increase in both the mean and the variance, even for the recent past conditions (20C3M). The latter case is an expected consequence of the GCM's characteristics, namely the known fact that the simulated meteorological fields by MIROC, or by other climate models, are biased and have too much variability. Accordingly, changes in the mean and in the standard deviation are due to climate change (signal) and to the limitations of BAM and GCM (noise) to properly reproduce the observed reality. With the aim of, at least reduce the model bias, the $\log _{10} \mathrm{BAJ} / \mathrm{A}$ obtained for the recent past conditions (20C3M scenario) were corrected to have mean and standard deviation equal to the observed values. Then, time series of $\log _{10} \mathrm{BAJ} / \mathrm{A}$ for the future scenarios were

transformed with exactly the same correction factors.

Comparison between future projections of the normal distributions may be performed on the basis of the descriptive statistics of the decimal logarithm of BA (Table 4). When compared with the present climate scenario $(20 \mathrm{C} 3 \mathrm{M})$, there are increases in the means of $\log _{10} \mathrm{BA}$ for both future climate scenarios periods, respectively of $7 \%$ and $11 \%(20 \%$ and $29 \%)$ from the $20 \mathrm{C} 3 \mathrm{M}$ to the $2051-2080$ and $2071-2100$ periods of the B1 (A1B) scenario. The standard deviation remains almost unchanged from the $20 \mathrm{C} 3 \mathrm{M}$ to the last (first) period of B1 (A1B) scenario, but presents a decrease (increase) of about $32 \%(28 \%)$ from the $20 \mathrm{C} 3 \mathrm{M}$ to the first 30 -year of B1 (A1B) scenario. It is also worth noting that differences in percentiles changes with increasing percentiles, e.g. from 0.39 (0.36) in P5 to 0.48 (0.57) in P50 and to -0.28 (0.38) in P95 when going from present climate to first (last) 30-year period

Table 4 - Descriptive statistics of corrected lognormal distributions of monthly burnt area for present (20C3M) and future (B1 and $A 1 B)$ climate scenarios. $P$ : percentiles, IQR: inter-quartile range, $R D$ : Relative dispersion.

\begin{tabular}{lccccc} 
& 20C3M & \multicolumn{2}{c}{ B1 } & \multicolumn{2}{c}{ A1B } \\
\hline & 1971-2000 & 2051-2080 & $\mathbf{2 0 7 1 - 2 1 0 0}$ & $\mathbf{2 0 5 1 - 2 0 8 0}$ & $\mathbf{2 0 7 1 - 2 1 0 0}$ \\
\hline Mean & 4.31 & 4.60 & 4.80 & 5.16 & 5.54 \\
SD & 0.54 & 0.37 & 0.54 & 0.49 & 0.69 \\
P5 & 3.60 & 3.99 & 3.96 & 4.35 & 4.46 \\
P10 & 3.65 & 4.23 & 4.20 & 4.55 & 4.65 \\
P25 & 3.94 & 4.43 & 4.44 & 4.79 & 5.14 \\
P50 & 4.21 & 4.69 & 4.79 & 5.20 & 5.47 \\
P75 & 4.63 & 4.85 & 5.11 & 5.48 & 5.89 \\
P90 & 5.20 & 5.01 & 5.48 & 5.68 & 6.41 \\
P95 & 5.36 & 5.08 & 5.75 & 5.94 & 6.83 \\
IQR & 0.69 & 0.43 & 0.66 & 0.69 & 0.76 \\
RD & 0.08 & 0.05 & 0.07 & 0.07 & 0.07
\end{tabular}

of B1 scenario while the correspondent differences for A1B scenario are even higher (about the double). This is an important aspect, since it reveals that in the B1 scenario conditions, for the $2051-2080$ period major increases in burnt area are only expected for values below P75 and the larger increases should be expected for P10 (0.58) values of burnt area while for the $2071-2100$ period the increases are therefore to be expected for all values of burnt area nonetheless larger increases are found between P10 (0.55) and P75 (0.47). A similar changing pattern is expected for A1B scenario during the first period but increasing changes may be expected from P5 (0.85) to P95 (1.47). As expected, differences are even more impressive when analysing changes in BA (and not in the logarithm) from present to future climate scenarios. The median may change from 16,000 ha in $20 \mathrm{C} 3 \mathrm{M}$ scenario to 49,000 ha $(158,000$ ha) and 61,000 ha (294,000 ha), respectively in the first and second 30-year period of B1 (A1B) scenario. On the other hand, the mean remains unchanged from recent past climate scenario to $2051-2080$ period of B1 but increase to 158,000 ha in the $2071-2100$ period of future scenario. Values of the mean BA for A1B scenario are even higher (270,000 and 1,500,000 ha). 


\section{Conclusions}

This study shown that the annual total BA in Continental Portugal is dominated by the fire events taking place in July and August which accounts for almost 3/4 of the total burnt area. The influence of weather conditions on the BA in these summer months was disclosed by the results of composite analysis of relevant meteorological variables performed for severe and mild years, defined as those where both the monthly BA of July and August are higher or lower than the respective upper or lower terciles, respectively. Results indicated that severe years are related to averaged anomalies of precipitation in March followed by positive anomalies of temperature and negative anomalies of precipitation and relative humidity in pre fire season. These climatic patterns are consistent with the atmospheric circulation over Portugal and with the anomalies of DSR becoming increasingly positive and statistically significant from May to June for severe years. Differences were also obtained during the fire season (July and August), where extreme meaningful positive anomalies of temperature and DSR (i.e., above the $90 \%$ significant level) were found for severe and negative for mild year composites.

These differences in the meteorological parameters have a profound impact on the life cycle and the thermal and hydric stress of the vegetation. In fact, during severe years a higher averaged precipitation and relative humidity in March increases the likelihood of a healthy growth of vegetation while the lower values of precipitation that follow in May and June, together with the higher values of temperature, increase the stress in a more abundant vegetation contributing to a larger amount of available fuels and burnt area. This process is particularly highlighted if, during the fire season, Portugal is affected by atmospheric circulation patterns that induce extreme hot and dry spells (heat waves) over the territory.

A Burnt Area Model (BAM) was developed to simulate the decimal logarithm of monthly burnt areas in July and August using, as predictors, the DSR during the pre-fire and the fire season. This model is able to explain almost $2 / 3$ of the total observed variance and is almost unaffected by over fitting which increase the confidence in their use in practice with future unknown validation dataset. The BAM was then fed with simulated data by the MIROC climate model respecting to present climate conditions $(20 \mathrm{C} 3 \mathrm{M})$ and to future climate IPCC emission scenario B1 and A1B and the bias of the BAM and GCM was corrected before proper comparison between projections of future BA.

When compared with the recent past climate scenario $(20 \mathrm{C} 3 \mathrm{M})$ with the two periods $(2051-2080$ and 2071 - 2100) of future climate scenarios B1 and A1B, increases in the means of the logarithm of July and August BA ranges, respectively between $7 \%$ and $11 \%$ for B1 and between $20 \%$ and $29 \%$ for A1B whereas the standard deviation remained almost unchanged in the latter case of scenario B1, presented a decrease of about $30 \%$ and $9 \%$ in the case of the former period of both B1 and A1B and an increase of $28 \%$ in the last period of A1B scenario. Differences in percentiles (between present and future climate scenarios) increased with increasing percentiles indicating that the larger increases in burnt area are to be expected for all fire events at the end of the XXI century.

It is very likely that the simulated BA are overestimated due, at least to three orders of reasons: $(i)$ the use of global (GCM) or regional (RCM) circulation models (which are just limited representations of the observed reality); (ii) the use of a linear BAM (which prevents the existence of feedback mechanisms that might reduce the amounts of burnt area); and, (iii) not taking into account other important factors for fire occurrence and size such as those related to changes in fuel structure (Pausas and Paula 2012; Gibson et al. 2014); climate-vegetation dynamics and conservation planning (Krawchuk et al. 2009); patterns of lightning strikes (Wotton et al. 2010; Wendler et al. 2011; Liu et al. 2012); and anthropogenic activities and drivers of fire, such as control over ignition, fire management, suppression activities, land use/land cover changes (Krawchuk et al. 2009; Le Page et al. 2010; Aldersley et al. 2011; Costa et al. 2011; Kloster et al. 2012). Nevertheless, obtained results are of the same order of magnitude of other similar studies (Le Goff et al. 2009; Carvalho et al. 2010; Westerling et al. 2011; Nitschke and Innes 2013). 
Finally, despite all the identified limitations, the developed approach consistently points towards an increasing of: ( $i$ ) the meteorological fire danger; (ii) having much larger fire events; (iii) inter-annual variability of the fire regime under future climate, which together with the positive bias will have dramatic consequences at the social, economic and environmental levels. These conclusions could be even more dramatic as an increase of the fire season length is very likely to be expected in boreal and temperate climates (Flannigan et al. 2009; Wotton et al. 2010; Carvalho et al. 2011; Westerling et al. 2011; Kloster et al. 2012).

\section{Acknowledgements}

This work was supported by national funds by FCT - Portuguese Foundation for Science and Technology, under the project PEst-OE/AGR/UI4033/2014 and by the project "SUSTAINSYS: Environmental Sustainable Agro-Forestry Systems" - NORTE-07-0124-FEDER-0000044. The authors are especially thankful to Dr. Manabu Abe, from Lab. Climate Risk Section, CGER, NIES, from Japan, for providing the MIROC data and to Cátia Pinto Teixeira for the spelling and grammar review of the manuscript.

\section{References}

Aldersley A, Murray SJ and Cornell SE (2011) Global and regional analysis of climate and human drivers of wildfire. Science of the Total Environment 409,3472-3481

Amiro BD, Logan K, Wotton B, Flannigan M, Todd J, Stocks B and Martell D (2005) Fire weather index system components for large fires in the Canadian boreal forest. International Journal of Wildland Fire 13,391-400

Batllori E, Parisien MA, Krawchuk MA and Moritz MA (2013) Climate change-induced shifts in fire for Mediterranean ecosystems. Global Ecology and Biogeography 22,1118-1129

Bedia J, Herrera S, Camia A, Moreno J and Gutiérrez JM (2014) Forest fire danger projections in the Mediterranean using ENSEMBLES regional climate change scenarios. Climatic Change 122,185199

Benson RP, Roads JO and Weise DR (2008) Climatic and weather factors affecting fire occurrence and behavior. Developments in Environmental Science 8,37-59

Calado T and DaCamara C (2008) in 'Dating fire events on end of season maps of burnt scars.' (Eds pp. 323-333. (Springer)

Cane D, Wastl C, Barbarino S, Renier L, Schunk C and Menzel A (2013) Projection of fire potential to future climate scenarios in the Alpine area: some methodological considerations. Climatic Change 119,733-746

Carvalho A, Carvalho A, Martins H, Marques C, Rocha A, Borrego C, Viegas D and Miranda A (2011) Fire weather risk assessment under climate change using a dynamical downscaling approach. Environmental Modelling \& Software 26,1123-1133

Carvalho A, Flannigan M, Logan K, Miranda AI and Borrego C (2008) Fire activity in Portugal and its relationship to weather and the Canadian Fire Weather Index System. International Journal of Wildland Fire 17,328-338

Carvalho A, Flannigan MD, Logan KA, Gowman LM, Miranda AI and Borrego C (2010) The impact of spatial resolution on area burned and fire occurrence projections in Portugal under climate change. Climatic Change 98,177-197

Cary GJ and Banks JC (2000) in 'Fire regime sensitivity to global climate change: an Australian perspective.' (Eds pp. 233-246. (Springer)

Chikamoto Y, Kimoto M, Ishii M, Mochizuki T, Sakamoto TT, Tatebe H, Komuro Y, Watanabe M, Nozawa T and Shiogama H (2013) An overview of decadal climate predictability in a multi-model ensemble by climate model MIROC. Climate Dynamics 40,1201-1222 
Clarke HG, Smith PL and Pitman AJ (2011) Regional signatures of future fire weather over eastern Australia from global climate models. International Journal of Wildland Fire 20,550-562

Costa L, Thonicke K, Poulter B and Badeck F-W (2011) Sensitivity of Portuguese forest fires to climatic, human, and landscape variables: subnational differences between fire drivers in extreme fire years and decadal averages. Regional Environmental Change 11,543-551

de Groot WJ, Flannigan MD and Cantin AS (2013) Climate change impacts on future boreal fire regimes. Forest Ecology and Management 294,35-44

Dee D, Uppala S, Simmons A, Berrisford P, Poli P, Kobayashi S, Andrae U, Balmaseda M, Balsamo G and Bauer P (2011) The ERA-Interim reanalysis: Configuration and performance of the data assimilation system. Quarterly Journal of the Royal Meteorological Society 137,553-597

Durão R and Corte-Real J (2006) Alterações climáticas: futuro dos acontecimentos extremos e do risco de incêndio. Incêndios Florestais em Portugal: Caracterização, Impactes e Prevenção 231-255

Efron B and Efron B (Eds) (1982) 'The jackknife, the bootstrap and other resampling plans.' (SIAM)

Efron B and Tibshirani RJ (Eds) (1994) 'An introduction to the bootstrap.' (CRC press)

Errasti I, Ezcurra A, Sáenz J and Ibarra-Berastegi G (2011) Validation of IPCC AR4 models over the Iberian Peninsula. Theoretical and Applied Climatology 103,61-79

Flannigan MD, Krawchuk MA, de Groot WJ, Wotton BM and Gowman LM (2009) Implications of changing climate for global wildland fire. International Journal of Wildland Fire 18,483-507

Gibson RK, Bradstock RA, Penman TD, Keith DA and Driscoll DA (2014) Changing dominance of key plant species across a Mediterranean climate region: implications for fuel types and future fire regimes. Plant Ecology 215,83-95

Hoinka KP, Carvalho A and Miranda AI (2009) Regional-scale weather patterns and wildland fires in central Portugal. International Journal of Wildland Fire 18,36-49

Johnstone JF, Chapin FS, Hollingsworth TN, Mack MC, Romanovsky V and Turetsky M (2010) Fire, climate change, and forest resilience in interior Alaska This article is one of a selection of papers from The Dynamics of Change in Alaska's Boreal Forests: Resilience and Vulnerability in Response to Climate Warming. Canadian Journal of Forest Research 40,1302-1312

Karali A, Hatzaki M, Giannakopoulos C, Roussos A, Xanthopoulos G and Tenentes V (2014) Sensitivity and evaluation of current fire risk and future projections due to climate change: the case study of Greece. Natural Hazards and Earth System Science 14,143-153

Kilpeläinen A, Kellomäki S, Strandman H and Venäläinen A (2010) Climate change impacts on forest fire potential in boreal conditions in Finland. Climatic Change 103,383-398

Kloster S, Mahowald N, Randerson J and Lawrence P (2012) The impacts of climate, land use, and demography on fires during the 21 st century simulated by CLM-CN. Biogeosciences 9,509-525

Krawchuk MA, Moritz MA, Parisien M-A, Van Dorn J and Hayhoe K (2009) Global pyrogeography: the current and future distribution of wildfire. PLoS One 4,e5102

Le Goff H, Flannigan MD and Bergeron Y (2009) Potential changes in monthly fire risk in the eastern Canadian boreal forest under future climate change. Canadian Journal of Forest Research 39,23692380

Le Page Y, Oom D, Silva J, Jönsson P and Pereira J (2010) Seasonality of vegetation fires as modified by human action: observing the deviation from eco-climatic fire regimes. Global Ecology and Biogeography 19,575-588

Liu Z, Yang J, Chang Y, Weisberg PJ and He HS (2012) Spatial patterns and drivers of fire occurrence and its future trend under climate change in a boreal forest of Northeast China. Global Change Biology 18,2041-2056

Lucarini V, Calmanti S, Dell'Aquila A, Ruti PM and Speranza A (2007) Intercomparison of the northern hemisphere winter mid-latitude atmospheric variability of the IPCC models. Climate Dynamics 28,829-848 
Lynch AH, Beringer J, Kershaw P, Marshall A, Mooney S, Tapper N, Turney C and Van Der Kaars S (2007) Using the paleorecord to evaluate climate and fire interactions in Australia. Annu. Rev. Earth Planet. Sci. 35,215-239

Meehl GA, Covey C, Taylor KE, Delworth T, Stouffer RJ, Latif M, McAvaney B and Mitchell JF (2007) The WCRP CMIP3 multimodel dataset: A new era in climate change research. Bulletin of the American Meteorological Society 88,1383-1394

Mochizuki T, Chikamoto Y, Kimoto M, Ishii M, Tatebe H, Komuro Y, Sakamoto TT, Watanabe M and Mori M (2012) Decadal prediction using a recent series of MIROC global climate models. 気 象集誌. 第 2 輯 90,373-383

Moriondo M, Good P, Durao R, Bindi M, Giannakopoulos C and Corte-Real J (2006) Potential impact of climate change on fire risk in the Mediterranean area. Climate research 31,85-95

Moritz MA, Parisien M-A, Batllori E, Krawchuk MA, Van Dorn J, Ganz DJ and Hayhoe K (2012) Climate change and disruptions to global fire activity. Ecosphere 3, art49

Murphy BF and Timbal B (2008) A review of recent climate variability and climate change in southeastern Australia. International Journal of Climatology 28,859-879

Nakicenovic N and Swart R (2000) Special report on emissions scenarios. Special Report on Emissions Scenarios, Edited by Nebojsa Nakicenovic and Robert Swart, pp. 612. ISBN 0521804930. Cambridge, UK: Cambridge University Press, July 2000. 1,

Nieto S and Rodríguez-Puebla C (2006) Comparison of precipitation from observed data and general circulation models over the Iberian Peninsula. Journal of climate 19,4254-4275

Nitschke CR and Innes JL (2013) Potential effect of climate change on observed fire regimes in the Cordilleran forests of South-Central Interior, British Columbia. Climatic Change 116,579-591

Palheiro PM, Fernandes P and Cruz MG (2006) A fire behaviour-based fire danger classification for maritime pine stands: comparison of two approaches. Forest Ecology and Management 234,S54

Pausas JG and Paula S (2012) Fuel shapes the fire-climate relationship: evidence from Mediterranean ecosystems. Global Ecology and Biogeography 21,1074-1082

Peel MC, Finlayson BL and McMahon TA (2007) Updated world map of the Köppen-Geiger climate classification. Hydrology and earth system sciences discussions 4,439-473

Pereira M, Malamud B, Trigo R and Alves P (2011) The history and characteristics of the 1980-2005 Portuguese rural fire database. Natural Hazards and Earth System Science 11,3343-3358

Pereira MG, Calado TJ, DaCamara CC and Calheiros T (2013) Effects of regional climate change on rural fires in Portugal. Climate research 57,187-200

Pereira MG, Trigo RM, da Camara CC, Pereira J and Leite SM (2005) Synoptic patterns associated with large summer forest fires in Portugal. Agricultural and Forest Meteorology 129,11-25

Pitman A, Narisma G and McAneney J (2007) The impact of climate change on the risk of forest and grassland fires in Australia. Climatic Change 84,383-401

Randall DA and Fichefet T (2007) Climate models and their evaluation.

Rocca ME, Brown PM, MacDonald LH and Carrico CM (2014) Climate change impacts on fire regimes and key ecosystem services in Rocky Mountain forests. Forest Ecology and Management

Scherrer SC (2011) Present-day interannual variability of surface climate in CMIP3 models and its relation to future warming. International Journal of Climatology 31,1518-1529

Silvestrini RA, Soares-Filho BS, Nepstad D, Coe M, Rodrigues H and Assunção R (2011) Simulating fire regimes in the Amazon in response to climate change and deforestation. Ecological Applications 21,1573-1590

Stocker TF, Qin D, Plattner G-K, Tignor M, Allen SK, Boschung J, Nauels A, Xia Y, Bex V and Midgley PM (2013) Climate change 2013: The physical science basis. Intergovernmental Panel on Climate Change, Working Group I Contribution to the IPCC Fifth Assessment Report (AR5)(Cambridge Univ Press, New York) 
Trigo RM, Pereira J, Pereira MG, Mota B, Calado TJ, Dacamara CC and Santo FE (2006) Atmospheric conditions associated with the exceptional fire season of 2003 in Portugal. International Journal of Climatology 26,1741-1757

Trigo RM, Sousa PM, Pereira MG, Rasilla D and Gouveia CM (2013) Modelling wildfire activity in Iberia with different atmospheric circulation weather types. International Journal of Climatology

Van Wagner C (Eds) (1987) 'Development and structure of the Canadian forest fire weather index system.')

Van Wagner C and Pickett T (Eds) (1985) 'Equations and FORTRAN program for the Canadian forest fire weather index system.')

Viegas D, Piñol J, Viegas M and Ogaya R (2001) Estimating live fine fuels moisture content using meteorologically-based indices. International Journal of Wildland Fire 10,223-240

Viegas DX, Reis RM, Cruz MG and Viegas MT (2004) Calibração do sistema canadiano de perigo de incêndio para aplicação em Portugal. Silva Lusitana 12,77-93

Watanabe M, Chikira M, Imada Y and Kimoto M (2011) Convective control of ENSO simulated in MIROC. Journal of climate 24,543-562

Watanabe S, Hajima T, Sudo K, Nagashima T, Takemura T, Okajima H, Nozawa T, Kawase H, Abe M and Yokohata T (2011) MIROC-ESM 2010: Model description and basic results of CMIP520c3m experiments. Geoscientific Model Development 4,845-872

Wendler G, Conner J, Moore B, Shulski M and Stuefer M (2011) Climatology of Alaskan wildfires with special emphasis on the extreme year of 2004. Theoretical and Applied Climatology 104,459472

Westerling A, Bryant B, Preisler H, Holmes T, Hidalgo H, Das T and Shrestha S (2011) Climate change and growth scenarios for California wildfire. Climatic Change 109,445-463

Wilks DS (Eds) (2011) 'Statistical methods in the atmospheric sciences.' (Academic press)

Wotton B, Nock C and Flannigan M (2010) Forest fire occurrence and climate change in Canada. International Journal of Wildland Fire 19,253-271

Wotton BM (2009) Interpreting and using outputs from the Canadian Forest Fire Danger Rating System in research applications. Environmental and Ecological Statistics 16,107-131 